\title{
FAKTOR-FAKTOR YANG MEMPENGARUHI KEPUTUSAN PETANI MENGGUNAKAN TEKNOLOGI PADA BUDIDAYA MANGGIS DI JAWA BARAT
}

\section{FACTORS INFLUENCE FARMER'S DECISIONS USING TECHNOLOGY IN MANGOSTEEN CULTIVATION IN WEST JAVA}

\author{
Dini Rochdiani*, Sulistyodewi Nur Wiyono, Kuswarini Kusno, \\ Lies Sulistyowati, Yosini Deliana, Sri Fatimah, Gema Wibawa Mukti \\ Fakultas Pertanian Universitas Padjadjaran \\ Jl. Raya Bandung-Sumedang KM 21 Jatinangor 45363 \\ *E-mail: dini17@unpad.ac.id dan dini.rochdiani@yahoo.co.id \\ (Diterima 25-07-2019; Disetujui 30-07-2019)
}

\begin{abstract}
ABSTRAK
Jumlah produksi manggis yang dihasilkan petani untuk tujuan ekspor masih rendah. Teknik budidaya dan penerapan teknologi yang berdaya guna belum sepenuhnya sesuai Standar Operasional Prosedur (SOP) dan Good Agricultural Practices (GAP), seperti penggunaan benih unggul, dosis cara dan waktu pemupukan, pengamatan dan pengendalian OPT, serta perlakuan panen dan pasca panen. Tujuan penelitian ini adalah mengidentifikasi faktor-faktor yang mempengaruhi keputusan petani menggunakan teknologi pada budidaya manggis. Metode penelitian yang digunakan adalah survey terhadap 69 petani manggis yang dipilih secara simple random sampling serta dianalisis menggunakan regresi dengan model System Equations. Hasil penelitian memperlihatkan, bahwa faktor-faktor yang mempengaruhi keputusan petani dalam menggunakan teknologi budidaya manggis untuk meningkatkan produksi dan kualitas hasil panen yaitu aset petani berupa asset fisik, non fisik dan ases akses petani. Aset fisik yaitu jumlah kepemilikan pohon, sawah, kendaraan, dan pendapatan di luar usahatani, aset non fisik yaitu jumlah anggota keluarga berusia produktif, dan aset akses petani yaitu lamanya waktu tempuh dari kebun ke jalan propinsi.
\end{abstract}

Kata kunci: Keputusan, petani, teknologi, manggis

\section{ABSTRACT}

The amount of mangosteen produced by farmers for export purposes is still low. Useful cultivation techniques and technology applications are not yet fully compliant with the Standard Operating Procedures (SOP) and Good Agricultural Practices (GAP), such as the use of superior seeds, dosage methods and times of fertilization, observation and control of pests, and harvest and post-harvest treatment. this is identifying the factors that influence farmers' decision to use technology in mangosteen cultivation. The research method used was a survey of 69 mangosteen farmers selected by simple random sampling and location selected by multistage random sampling. The factor analysis was used Regression with System Equations Model. The results of the study show that the factors that influence farmers' decision to use mangosteen cultivation technology to increase production and quality of crops are farmers' assets, namely physical assets, non-physical assets and access to farmers' access. Physical assets, namely the number of ownership of trees, rice fields, vehicles, and income outside of farming; Non-physical assets, namely the number of productive age family members, farmers' access assets, namely the length of travel time from the garden to the provincial road.

Keywords: Decisions, farmers, technology, mangosteen 


\section{PENDAHULUAN}

Manggis (Queen of Tropical Fruit) merupakan salah satu komoditas primadona ekspor buah andalan Indonesia yang memberikan kontribusi besar pada devisa negara dan pendapatan petani. Tujuan ekspor manggis yaitu Hongkong, Taiwan, RRC. Sentra produksi manggis terbesar di Indonesia adalah Jawa Barat, antara lain Tasikmalaya dan Purwakarta (Dinas Perkebunan, 2017).

Budidaya manggis cocok pada daerah yang memiliki tanah yang subur, gembur, mengandung bahan organik. Derajat kemasaman tanah ( $\mathrm{pH}$ tanah) ideal adalah 5-7. Tanaman manggis dapat tumbuh di daerah dataran rendah sampai pada ketinggian $1.000 \mathrm{~m}$ di atas permukaan laut (dpl). Pertumbuhan terbaik pada daerah dengan ketinggian di bawah 500-600 m dpl, memiliki drainase baik tidak tergenang serta air tanah berada pada kedalaman 50-200 meter (Poerwanto, 2000). Saat ini tanaman manggis sudah banyak dilakukan oleh para petani Indonesia, apalagi banyak ahli yang menemukan berbagai khasiat dan manfaat dari tanaman buah manggis untuk kesehatan tubuh manusia, mulai dari daging sampai kulitnya. Kulit buah mengandung getah kuning yang terasa pahit, jika buah muda dilukai maka getah kuning akan menetes keluar (Qosim, 2007).

Permintaan buah manggis semakin hari semakin meningkat yaitu rata-rata $50 \%$ per tahun dan hal ini seharusnya dapat menjadikan peluang untuk mengembangkan usaha agribisnis manggis bagi para petani Indonesia. Namun kenyataannya, potensi ekonomi tersebut belum tergali karena permintaan manggis 200 ton per hari, hanya dapat terpenuhi 100 ton per hari (baru 50\% terpenuhi) (Rochdiani dkk, 2018).

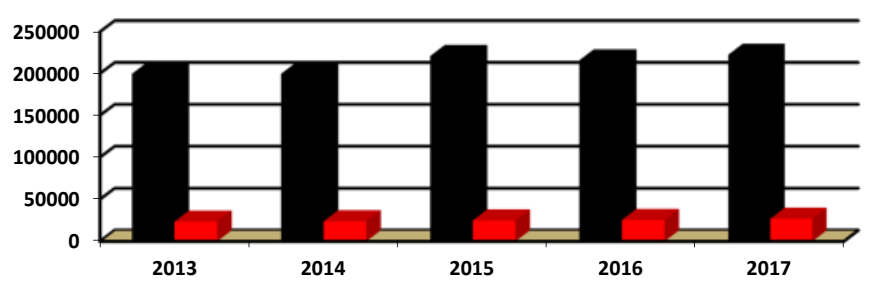

Gambar 1. Perkembangan Produksi dan Ekspor Manggis di Indonesia, Tahun 20132017 (dalam Ton) (BPS, 2018)

Rendahnya ekspor buah manggis hasil perkebunan rakyat disebabkan oleh produsen lokal belum mampu memenuhi kualitas manggis sesuai permintaan konsumen pasar dan standar pasar internasional (Firdaus, 2013). Untuk menghasilkan produksi manggis yang berkualitas serta berkelanjutan dibutuhkan pengelolaan yang intensif dengan penerapan teknologi yang tepat. Masalahnya, walau teknologi dan cara pembudidayaan manggis yang intensif 
telah diperkenalkan oleh pemerintah tetapi petani memiliki persepsi yang berbeda sehingga penggunaan teknologi dan praktek budidaya yang dianjurkan keberhasilannya masih sangat terbatas. Masalah lain, masih banyaknya hambatan dalam penerapan teknologi budidaya yang dipengaruhi faktor internal dan eksternal petani yang menyebabkan produksi manggis nasional tidak stabil dan kualitasnya rendah dan sedikit yang dapat diekspor (sekitar 20\%) (BPS, 2018). Akibatnya manggis Indonesia kurang dapat bersaing dengan manggis dari negara lain seperti Malaysia, Thailand dan Amerika Latin.

Faktor-faktor yang mempengaruhi keputusan petani (on farm) terutama dalam penerapan teknologi budidaya, antara lain faktor yang mempengaruhi output, faktor yang mempengaruhi adopsi penggunaan tenaga kerja dan faktor yang mempengaruhi adopsi penggunaan pupuk. menyebabkan produksi dan produktivitas manggis nasional tidak stabil dan kualitasnya rendah. Menurut Daryanto (2013), produktivitas adalah sebuah konsep yang menggambarkan hubungan antara hasil (jumlah barang dan atau jasa yang diproduksi) dengan sumber (jumlah tenaga kerja, modal, tanah, energi, dan sebagainya) untuk menghasilkan hasil tersebut (output). Menurut Smith dan Wekeley (1995) dalam Qanti (2014), produktivitas adalah produksi atau output yang dihasilkan dalam satu kesatuan waktu untuk input.

Dalam kenyataannya, petani membuat keputusan dalam penggunaan pupuk, belum sepenuhnya melaksanakan sesuai Standar Operasional Prosedur (SOP) dan Good Agricultural Practices $(G A P)$, seperti dosis, cara dan waktu pemupukan, Kondisi ini menyebabkan tanaman manggis kurang baik pertumbuhannya dan mengakibatkan produksi rendah. Tujuan penelitian ini adalah mengidentifikasi faktor-faktor yang mempengaruhi keputusan petani menggunakan teknologi pada budidaya manggis.

\section{METODE PENELITIAN}

Metode penelitian yang digunakan adalah survey terhadap 69 petani manggis di Jawa Barat yang tergabung di Gapoktan Artamukti Pusaphiang Tasikmalaya (47 petani) dan Gapoktan Sulanjana Wanayasa Purwakarta (22 petani). Pemilihan responden diambil secara simple random sampling dan lokasi penelitian dipilih secara multistage random sampling. 
Untuk menganalisis faktor-faktor yang berpengaruh pada keputusan petani dalam menggunakan teknologi budidaya manggis untuk meningkatkan produksi dan kualitas hasil panen dianalisis secara regresi dengan model System Equations. Menurut Feder et al (1985), kerangka berpikir yang lengkap untuk melihat proses adopsi di tingkat petani harus didasarkan pada proses pembuatan keputusan yang dilakukan oleh petani.

$$
\begin{aligned}
L=u\left(c, z^{h}\right)+ & \lambda\left[\sum_{i \in T} p_{i}\left(q_{i}-E_{i}-c_{i}\right)+S\right]+\eta\left[\sum_{i \in T C} p_{i}\left(q_{i}-E_{i}-c_{i}\right)+K\right]+\emptyset g\left(q, z^{q}\right) \\
& +\sum_{i \in N T} \mu_{i}\left(q_{i}-E_{i}-c_{i}\right)
\end{aligned}
$$

Dalam penelitian ini terdapat satu persamaan output dan tiga persamaan untuk permintaan input. Variabel terikat yang digunakan adalah sebagai berikut:

1) Produksi manggis didefinisikan sebagai hasil panen per pohon dalam satuan kilogram untuk selama satu musim.

2) Penggunaan tenaga kerja, didefinisikan sebagai total pengeluaran per pohon manggis untuk tenaga kerja (baik tenaga kerja dalam keluarga maupun luar keluarga) selama satu musim. Untuk perhitungan tenaga kerja dalam keluarga dihitung berdasarkan jumlah hari kerja tenaga kerja dalam keluarga dikalikan dengan
Pada umumnya, keputusan petani pada waktu periode tertentu diasumsikan berasal dari maksimalisasi.. Model keputusan petani secara sederhana adalah sebagai berikut:

$$
\max _{c, q} u\left(c, z^{h}\right)
$$

Berdasarkan problem maksimalisasi dan batasan-batasan tersebut, maka diperoleh persamaan sebagai berikut: rata-rata upah tenaga kerja pertanian di level desa.

3) Pemakaian pupuk, didefinisikan sebagai total penggunaan pupuk per pohon (dalam satuan kilogram) yang digunakan dalam proses produksi manggis.

Variabel bebas yang akan digunakan dalam persamaan ini adalah sebagai berikut:

(1) Vektor harga eksogen, diwakilkan oleh:

a. Waktu tempuh dari kebun ke jalan provinsi: harga input eksogen akan dipengaruhi oleh biaya transaksi yang melibatkan pemindahan input dari distributor /toko input ke kebun atau pemindahan output ke 
pasar/pembeli, sehingga waktu tempuh dianggap tepat. Waktu tempuh diduga berpengaruh negatif untuk keempat variabel terikat. Semakin lama waktu tempuh diduga harga input yang harus ditanggung akan semakin besar dan semakin besar biaya transaksi untuk penawaran output.

b. Populasi supplier input di lingkup desa: variabel ini diduga berpengaruh positif terhadap penggunaan input dan produksi dari output. Biaya transaksi untuk membeli input akan lebih kecil jika jumlah supplier input semakin banyak. Efek kompetisi dari banyaknya jumlah supplier input juga akan membuat harga input lebih rendah. Hal ini akan mendorong petani untuk menggunakan lebih banyak input dan meningkatkan output.

(2) Vektor aset sosial, diwakilkan oleh:

a. Jumlah tahun pendidikan petani: variabel ini bisa memiliki pengaruh positif maupun negatif. Semakin tinggi tingkat pendidikan bisa membantu petani untuk lebih adaptif terhadap inovasi, akan tetapi peningkatan biaya oportunitas dari penggunaan waktu petani akan mengurangi ketersediaan waktu petani untuk produksi manggis.

b. Jumlah anggota keluarga produktif (berusia 15-64 tahun): variabel ini diduga memiliki pengaruh negatif terhadap adopsi teknologi. Semakin banyak jumlah anggota keluarga yang produktif, kemungkinan akan mengurangi adopsi input karena petani bisa menggunakan tenaga kerja keluarga sebagai pengganti teknologi.

(3) Vektor aset fisik, diwakilkan oleh:

a. Total jumlah pohon manggis yang dimiliki, sebagai proxy untuk tingkat kekayaan dan skala petani. Variabel ini bisa memberikan pengaruh positif maupun negatif terhadap adopsi teknologi. Penggunaan input dan tenaga kerja dapat dipengaruhi oleh skala ekonomi petani. Berbeda halnya untuk petani yang memiliki tingkat densitas pohon yang tinggi, penggunaan input bisa jadi lebih tinggi jika sanitari lingkungan kebun tidak baik (menyebabkan tingginya serangan hama dan penyakit). 
b. Memiliki sawah: variabel ini adalah variabel dummy sebagai proxy untuk tingkat kekayaan rumah tangga petani. Variabel ini bisa memiliki pengaruh positif maupun negatif. Variabel ini bisa berdampak positif karena variabel ini bisa digunakan sebagai sumber likuiditas untuk pembiayaan usahatani. Akan tetapi variabel ini juga bisa memiliki pengaruh negatif terhadap adopsi teknologi dan output karena ada kemungkinan petani lebih mengutamakan usahatani padinya dibandingkan manggis.

c. Memiliki kendaraan: variabel ini diduga memiliki pengaruh positif terhadap penggunaan input dan peningkatan output. Hal ini sesuai dengan temuan Qanti (2014) bahwa kepemilikan kendaraan secara signifikan berpengaruh positif terhadap adopsi pestisida, pupuk, dan juga output.

d. Pendapatan petani dari luar usahatani setahun sebelumnya: variabel ini didefinisikan sebagai pendapatan yang berasal dari luar sektor pertanian. Variabel ini bisa memiliki pengaruh positif maupun negatif. Semakin besar pendapatan petani di luar pertanian bisa digunakan sebagai sumber pembiayaan dalam usahatani manggis sehingga dapat meningkatkan penggunaan input dan meningkatkan output. Akan tetapi, pendapatan dari luar usahatani yang besar juga bisa menyebabkan fokus petani teralihkan dari usahatani manggis sehingga dapat mengurangi pemakaian input dan mengurangi output.

\section{HASIL DAN PEMBAHASAN}

Faktor-faktor yang Mempengaruhi Keputusan Petani Menggunakan Teknologi pada Budidaya Manggis

Faktor-faktor yang berpengaruh pada keputusan petani dalam menggunakan teknologi budidaya manggis untuk meningkatkan produksi dan kualitas hasil panen dapat dilihat dari hasil faktor-faktor yang mempengaruhi output dan permintaan input sebagai bentuk dari adopsi teknologi. Hasil regresi secara simultan dari tiga persamaan adopsi disajikan pada Tabel 1 . 
Tabel 1. Output, Input dan Adopsi Teknologi oleh Petani Manggis

\begin{tabular}{|c|c|c|c|}
\hline Variabel independen & $\begin{array}{l}\text { Produktivitas } \\
\text { Manggis } \\
\text { (ton/musim) }\end{array}$ & $\begin{array}{l}\text { Biaya Tenaga } \\
\text { kerja (Rp/ } \\
\text { musim/pohon) }\end{array}$ & $\begin{array}{l}\text { Jumlah pupuk } \\
\text { (kg/musim/ } \\
\text { pohon) }\end{array}$ \\
\hline \multirow[t]{2}{*}{ 1. Waktu tempuh dari kebun ke jalan provinsi (menit) } & $0,272 * *$ & $-46,927$ & $-0,383^{* *}$ \\
\hline & $(0,060)$ & $(0,658)$ & $(0,037)$ \\
\hline \multirow[t]{2}{*}{ 2. Jumlah penjual input di desa (unit) } & 4,474 & 830,116 & $-4,339$ \\
\hline & $(0,285)$ & $(0,786)$ & $(0,413)$ \\
\hline \multirow[t]{2}{*}{ 3.Tingkat pendidikan kepala keluarga (tahun) } & $-0,544$ & 252,228 & 1,306 \\
\hline & $(0,534)$ & $(0,694)$ & $(0,239)$ \\
\hline \multirow[t]{2}{*}{ 4. Jumlah anggota keluarga berusia produktif (orang) } & $-2,198$ & $2289,189 *$ & $5,313 * *$ \\
\hline & $(0,245)$ & $(0,098)$ & $(0,027)$ \\
\hline \multirow[t]{2}{*}{ 5. Jumlah pohon manggis yang dimiliki (pohon) } & $-0,041 *$ & $-11,004$ & $0,103 * * *$ \\
\hline & $(0,100)$ & $(0,562)$ & $(0,002)$ \\
\hline \multirow[t]{2}{*}{ 6. Memiliki lahan sawah di tahun lalu $(1=$ ya $)$} & $-10,871$ & $12706,68 * *$ & $28,357 * * *$ \\
\hline & $(0,223)$ & $(0,050)$ & $(0,012)$ \\
\hline \multirow{2}{*}{ 7. Memiliki kendaraan di tahun lalu $(1=$ ya $)$} & $-0,939$ & $16154,51 * *$ & $19,564^{*}$ \\
\hline & $(0,916)$ & $(0,013)$ & $(0,081)$ \\
\hline \multirow[t]{2}{*}{ 8.Jumlah pendapatan di luar usahatani di tahun lalu (Rp) } & $0,001 * *$ & $-0,001$ & $-0,001$ \\
\hline & $(0,050)$ & $(0,237)$ & $(0,575)$ \\
\hline \multirow[t]{2}{*}{ 9. Konstanta } & $31,423 * *$ & $26853,87 * *$ & $-27,712$ \\
\hline & $(0,049)$ & $(0,027)$ & $(0,189)$ \\
\hline Observations & 69 & 69 & 69 \\
\hline P-value & 0,003 & 0,001 & 0,001 \\
\hline \multicolumn{4}{|c|}{ Breusch-Pagan test of independence: $\operatorname{chi} 2(3)=17,683, \operatorname{Pr}=0,0005$} \\
\hline \multicolumn{4}{|l|}{ Matriks korelasi dari residual: } \\
\hline Produksi & 1,0000 & & \\
\hline Tenaker & 0,0591 & 1,0000 & \\
\hline Pemupukan & 0,1581 & 0,4773 & 1,0000 \\
\hline
\end{tabular}

*,***** menandakan signifikansi pada tingkat kepercayaan 90\%,95\%, 99\%. Nilai P-value berada dalam tanda kurung

Tabel 1 menunjukkan tingkat signifikansi dan bagaimana arah hubungan antara variabel dependen dan variabel independen. Koefisien yang tertera dalam Tabel 1 tidak menggambarkan besarnya (magnitude) hubungan dari variabel dependen dan independen. Besarnya hubungan dari variabel dependen dan independen bisa dilihat pada Tabel 2 dimana koefisien yang diperoleh merupakan nilai efek marginal atau elastisitas dari variabelvariabel independen.

\section{Faktor yang mempengaruhi Output}

Tabel 1 memperihatkan bahwa ada tiga variabel yang secara signifikan mempengaruhi besar kecilnya produktivitas pohon manggis yang dimiliki oleh petani.

$$
\text { Variabel pertama yang }
$$
mempengaruhi produktivitas manggis adalah lamanya waktu tempuh dari kebun ke jalan provinsi. Lamanya waktu tempuh ini berpengaruh secara positif terhadap produktivitas manggis, yang berarti bahwa semakin lama jarak tempuh dari kebun ke jalan provinsi maka semakin 
besar produktivitas pohon. Tabel 2 memperihatkan, bahwa penambahan lama waktu tempuh dari kebun ke jalan provinsi selama satu menit akan menyebabkan peningkatan produktivitas manggis 0,331 ton/musim.

Variabel kedua yang mempengaruhi produktivitas manggis adalah jumlah pohon manggis yang dimiliki. Banyaknya jumlah pohon manggis yang dimiliki ini berpengaruh secara negatif terhadap produktivitas manggis, yang berarti bahwa semakin banyak pohon yang dimiliki petani maka semakin kecil produktivitas pohonnya. Tabel 2 memperlihatkan bahwa penambahan satu pohon manggis akan menyebabkan penurunan produktivitas manggis 0,187 ton/musim.

Tabel 2. Marginal Effect (elastisitas) Variabel Independen terhadap Output, Input, dan Adopsi Teknologi oleh Petani Manggis

\begin{tabular}{lrrr}
\hline Variabel independen & $\begin{array}{l}\text { Produktivitas } \\
\text { Manggis } \\
\text { (ton/musim) }\end{array}$ & $\begin{array}{l}\text { Biaya Tenaga } \\
\text { kerja (Rp/ } \\
\text { musim/pohon) }\end{array}$ & $\begin{array}{l}\text { Jumlah pupuk } \\
\text { (kg/musim/ } \\
\text { pohon) }\end{array}$ \\
\hline 1. Waktu tempuh dari kebun ke jalan provinsi (menit) & $0,331^{* *}$ & $-0,026$ & $-0,376^{* *}$ \\
2. Jumlah penjual input di desa (unit) & 0,252 & 0,021 & $-0,198$ \\
3. Tingkat pendidikan kepala keluarga (tahun) & $-0,152$ & 0,032 & 0,296 \\
4. Jumlah anggota keluarga berusia produktif (orang) & $-0,236$ & $0,111^{*}$ & $0,461^{* *}$ \\
5. Jumlah pohon manggis yang dimiliki (pohon) & $-0,187 *$ & $-0,022$ & $0,374^{* * *}$ \\
6. Memiliki lahan sawah di tahun lalu (1= ya) & $-0,389$ & $0,205^{* *}$ & $0,819^{* * *}$ \\
7. Memiliki kendaraan di tahun lalu (1= ya) & $-0,032$ & 0,253 & $0,548^{*}$ \\
8. Jumlah pendapatan di luar usahatani di tahunlalu(Rp) & $0,033 * *$ & $-0,041$ & $-0,060$ \\
\hline ***,*** menandakan signifikansi pada tingkat kepercayaan90\%,95\%, 99\%. Nilai P-value berada dalam \\
tanda kurung
\end{tabular}

Variabel ketiga yang mempengaruhi produktivitas manggis adalah besarnya pendapatan di luar usahatani. Besarnya pendapatan di luar usahatani berpengaruh secara positif terhadap produktivitas manggis, yang berarti bahwa semakin besar pendapatan di luar usahatani maka semakin besar produktivitas pohon. Tabel 2 memperlihatkan bahwa penambahan besarnya pendapatan di luar usahatani sebesar satu rupiah akan menyebabkan peningkatan produktivitas manggis 0,033 ton/musim.

\section{Faktor yang Mempengaruhi Adopsi Penggunaan Tenaga Kerja}

Tabel 1 menunjukkan bahwa ada tiga variabel yang secara signifikan mempengaruhi besar kecilnya penggunaan biaya tenaga kerja untuk setiap pohon dalam satu musim.

Variabel pertama yang mempengaruhi biaya tenaga kerja adalah jumlah anggota keluarga berusia produktif. Jumlah anggota keluarga berusia produktif ini berpengaruh secara positif terhadap biaya tenaga kerja, yang 
berarti bahwa semakin banyak jumlah anggota keluarga berusia produktif maka semakin besar biaya tenaga kerja yang dipergunakan. Hal ini dimungkinkan karena dalam penghitungan biaya tenaga kerja ini, biaya tenaga kerja dalam keluarga juga dihitung sebagaimana menggunakan tenaga kerja di luar keluarga. Hal ini juga mengindikasikan bahwa petani relatif banyak menggunakan tenaga kerja dalam keluarga dalam kegiatan produksinya. Tabel 2 menjelaskan bahwa penambahan anggota keluarga berusia produktif satu orang akan menyebabkan peningkatan biaya tenaga kerja Rp 0,111/musim/pohon.

Variabel kedua yang mempengaruhi biaya tenaga kerja adalah kepemilikan lahan sawah sebagai salah satu bentuk dari modal fisik (kekayaan) yang dimiliki oleh petani. Kepemilikan lahan sawah ini berpengaruh secara positif terhadap biaya tenaga kerja, yang berarti bahwa petani yang memiliki sawah akan mengeluarkan biaya tenaga kerja yang dipergunakan lebih tinggi dibandingkan dengan petani yang tidak memiliki sawah. Tabel 2 memperlihatkan bahwa petani yang memiliki sawah mengeluarkan biaya tenaga kerja lebih tinggi dari petani yang tidak memiliki sawah Rp 0,205/musim/ pohon.
Variabel ketiga yang mempengaruhi biaya tenaga kerja adalah kepemilikan kendaraan sebagai salah satu bentuk dari modal fisik (kekayaan) yang dimiliki oleh petani dan kemudahan akses bagi petani. Kepemilikan kendaraan ini berpengaruh secara positif terhadap biaya tenaga kerja, yang berarti bahwa petani yang memiliki kendaraan akan mengeluarkan biaya tenaga kerja yang dipergunakan lebih tinggi dibandingkan dengan petani yang tidak memiliki kendaraan. Tabel 2 memperlihatkan bahwa petani yang memiliki kendaraan mengeluarkan biaya tenaga kerja lebih tinggi dari petani yang tidak memiliki kendaraan $\mathrm{Rp}$ 0,253/ musim/pohon.

\section{Faktor yang mempengaruhi Adopsi penggunaan Pupuk}

Tabel 1 memperlihatkan bahwa ada lima variabel yang secara signifikan mempengaruhi besar kecilnya pemakaian pupuk untuk pohon manggis yang dimiliki oleh petani.

$$
\text { Variabel pertama yang }
$$
mempengaruhi adopsi penggunaan pupuk adalah lamanya waktu tempuh dari kebun ke jalan provinsi. Lamanya waktu tempuh ini berpengaruh secara negatif terhadap jumlah pupuk yang digunakan untuk setiap pohon, yang berarti bahwa semakin 
lama jarak tempuh dari kebun ke jalan provinsi maka semakin kecil jumlah pupuk yang dipergunakan. Hal ini dimungkinkan karena biaya transaksi untuk perolehan input yang tinggi. Dengan artian bahwa semakin jauh jarak kebun dengan akses transportasi yang memadai maka semakin sulit petani untuk mendapatkan input dan akhirnya penggunaan input pupuk per pohonnya menjadi semakin kecil. Tabel 2 menunjukkan bahwa penambahan lama waktu tempuh dari kebun ke jalan provinsi sebesar satu menit akan menyebabkan penurunan penggunaan pupuk 0,376 $\mathrm{kg} / \mathrm{musim} /$ pohon.

Variabel kedua yang mempengaruhi adopsi penggunaan pupuk adalah jumlah anggota keluarga berusia produktif. Jumlah anggota keluarga berusia produktif ini berpengaruh secara positif terhadap jumlah pupuk yang digunakan untuk setiap pohon, yang berarti bahwa semakin banyak jumlah anggota keluarga berusia produktif maka semakin besar jumlah pupuk yang dipergunakan. Hal ini dimungkinkan karena semakin untuk melakukan pemupukan diperlukan curahan tenaga kerja yang tidak sedikit. Dengan adanya supply tenaga kerja dalam keluarga mendorong petani untuk mengadopsi melalui penggunaan pupuk.
Tabel 2 memperlihatkan bahwa penambahan satu orang tenaga kerja produktif dalam keluarga akan menyebabkan peningkatan penggunaan pupuk $0,461 \mathrm{~kg} / \mathrm{musim} /$ pohon.

Variabel ketiga yang mempengaruhi adopsi penggunaan pupuk adalah jumlah pohon manggis yang dimiliki oleh petani. Jumlah pohon manggis yang dimiliki ini berpengaruh secara positif terhadap jumlah pupuk yang digunakan untuk setiap pohon, yang berarti bahwa semakin banyak jumlah pohon manggis yang dimiliki maka semakin besar jumlah pupuk yang dipergunakan untuk setiap pohonnya. Hal ini dimungkinkan karena semakin banyak pohon yang dimiliki maka kemungkinan untuk menjadikan pohon manggis sebagai sumber pendapatan utama, sehingga kemungkinan untuk petani lebih peduli terhadap pohon manggisnyapun akan menjadi semakin besar. Tabel 2 menunjukkan bahwa penambahan satu pohon manggis yang dimiliki oleh petani akan menyebabkan peningkatan penggunaan pupuk 0,374 $\mathrm{kg} / \mathrm{musim} /$ pohon.

$$
\text { Variabel keempat yang }
$$
mempengaruhi adopsi penggunaan pupuk adalah kepemilikan sawah oleh petani. Kepemilikan sawah ini berpengaruh secara positif terhadap jumlah pupuk yang 
digunakan untuk setiap pohon, yang berarti bahwa petani yang memiliki sawah memiliki kemungkinan menggunakan jumlah pupuk yang lebih besar dari petani yang tidak memiliki sawah. Hal ini dimungkinkan karena sawah sebagai indikasi dari kepemilikan modal petani. Selain itu juga biasanya jika petani yang memiliki sawah akan memberikan pupuk untuk padinya dan ketika mereka membeli pupuk untuk padi maka kemungkinan mereka untuk membeli pupuk untuk pohon manggisnya juga semakin besar (karena bagaimana pun mereka tetap harus membeli pupuk untuk padinya). Tabel 2 memperlihatkan bahwa petani yang memiliki sawah (petani pemilik penggarap dan menggunakan pupuk lebih banyak dibandingkan dengan petani yang tidak memiliki sawah dengan tingkat penggunaan pupuk 0,819 $\mathrm{kg} / \mathrm{musim} /$ pohon lebih banyak dari petani yang tidak memiliki sawah (petani penggarap/ penyakap).

Variabel kelima yang mempengaruhi adopsi penggunaan pupuk adalah kepemilikan kendaraan oleh petani. Kepemilikan kendaraan ini berpengaruh secara positif terhadap jumlah pupuk yang digunakan untuk setiap pohon, yang berarti bahwa petani yang memiliki kendaraan memiliki kemungkinan menggunakan jumlah pupuk yang lebih besar dari petani yang tidak memiliki kendaraan. Hal ini dimungkinkan karena dengan memiliki kendaraan, petani memiliki akses yang lebih baik kepada pupuk (kemudahan memperoleh pupuk dari toko input yang biasanya ada di kecamatan atau lokasi lainnya). Tabel 2 memperlihatkan bahwa petani yang memiliki kendaraan untuk kegiatan usahataninya, umumnya menggunakan pupuk lebih banyak dibandingkan dengan petani yang tidak memiliki kendaraan dengan tingkat penggunaan pupuk $\quad 0,548$ $\mathrm{kg} / \mathrm{musim} /$ pohon lebih banyak dari petani yang tidak memiliki kendaraan.

\section{Simultanitas Persamaan dan Korelasi antara Variabel Dependen}

Tabel 1 juga memperlihatkan Breusch-Pagan test dengan nilai $\mathrm{P}=0.000$ menjelaskan bahwa error term dari ketiga persamaan ini signifikan bukan 0 . Hal ini menunjukkan bahwa ketiga persamaan ini memiliki hubungan satu sama lain, yang artinya bahwa keputusan untuk mengadopsi salah satu teknologi mempengaruhi keputusan dalam mengadopsi teknologi lainnya (sesuai dengan yang dijelaskan oleh Feder et al, 1985). Sehingga jika persamaan ini diregresi secara terpisah dengan 
menggunakan regresi OLS biasa, akan menjadi kurang tepat dan hasilnya tidak akan sebaik jika ketiga persamaan ini diregresi secara simultan.

Matrik korelasi antara ketiga persamaan ini menunjukkan bahwa ketiga persamaan ini saling mempengaruhi secara positif dengan derajat pengaruh dari persamaan produktivitas dan biaya tenaga kerja 0,0591 dan derajat pengaruh dari persamaan produktivitas dan jumlah penggunaan pupuk 0,1581 . Jika dilihat dari magnitudenya, nilai ini cukup kecil, namun jika dilihat dari segi signifikansinya, maka tetap ketiga persamaan ini memiliki keterkaitan.

\section{KESIMPULAN DAN SARAN}

\section{Kesimpulan}

Faktor-faktor yang berpengaruh terhadap keputusan petani dalam menggunakan teknologi budidaya manggis untuk meningkatkan produksi dan kualitas hasil panen, yaitu: aset petani yang terdiri atas aset fisik maupuk non fisik, serta akses untuk menempuh pasar yang harus ditempuh petani untuk menjual hasil. Aset fisik diwakili oleh jumlah kepemilikan pohon, kepemilikan sawah, kepemilikan kendaraan, dan pendapatan di luar usahatani. Aset non fisik diwakili oleh jumlah anggota keluarga berusia produktif. Aset akses diwakili oleh lamanya waktu tempuh dari kebun ke jalan propinsi.

\section{Saran}

1. Perlu adanya peningkatan softskill bagi para petani melalui pelatihanpelatihan atau workshop mengenai teknik budidaya dan penerapan teknologi yang berdaya guna sesuai Standar Operasional Prosedur (SOP) dan Good Agricultural Practices $(G A P)$, seperti penggunaan benih unggul, dosis cara dan waktu pemupukan, pengamatan dan pengendalian OPT, serta perlakuan panen dan pasca panen.

2. Perlu diciptakan suatu inovasi teknologi produksi yang dapat menghasilkan buah manggis secara out off season technology.

3. Teknologi percepatan proses pembungaan yaitu dengan cara memperbaiki sistem perakaran dan mempercepat fase juvenil. Teknologi ini menggunakan zat pengatur tumbuh IBA antara 50-100 ppm, serta proses memperpendek fase juvenil dari $10 \mathrm{ke}$ 7 tahun menggunakan metode grafting (cangkokan) mata tunas ke induknya.

\section{DAFTAR PUSTAKA}

BPS. 2018. Statistik Perkebunan. BPS. Jakarta. 
Daryanto, 2013. Kewirausahaan.

Gavamedia. Yogyakarta.

Dini Rochdiani, dkk.,2014. Analisis

Sistem Sosial Ekonomi Petani

Mangga. FakultasPertanian Unpad.

Bandung.

Dini Rochdiani, dkk,

2018.Pengembangan Usaha dan

Kelembagaan Tataniaga serta

Tingkat Penerapan Teknologi untuk meningkatkan Daya Saing pada

Agribisnis Manggis. Laporan Akhir

PUPT. Fakultas Pertanian

Universitas Padjadjaran.

Dinas Perkebunan, 2017. Laporan

Tahunan. Dinas Perkebunan

Provinsi Jawa Barat.

Dirjen Hortikultura. 2017. Laporan

Tahunan. Dirjen Hortikultura.

Jakarta.

Feder, G., Just, R.E and D. Zilberman.

1985. 'Adoption of Agricultural

Innovations in Developing

Countries: A Survey'. Economic

Development and Cultural Change

33, no. 2 (1985): 255-298

Firdaus dan Wagiono, 2013. Daya Saing

Sistim Pemasaran Manggis

Indonesia. PSE, Bogor.
Goose, Bishwahep., 2012. Pushing the Boundries of Formalization Towards More Inclusive? Paper presented at Meeting Small-Scale Farmers in Their Markets:

Understanding and Improving the Institutions and Governance of Informal. Agrifood Trade held in Amsterdam November 29-30, 2012.

Poerwanto. 2000. Teknologi Budidaya Manggis. Prosiding Pemantapan Teknologi Spesifik Lokasi Wilayah Barat Melalui Temu Pakar. Bogor.

Qanti, Sara Ratna. 2014.'Determinants of Mango Farmer Choices of Modern vs. Traditional Market Channels and Farm Technology Intensification in Java Indonesia'. Unpublished Thesis. Michigan State University, USA.

Qosim. 2007b. Kulit Buah Manggis sebagai Anti Oksidan. Harian Umum Pikiran Rakyat Edisi 15 Februari 2007. Pikiran Rakyat . Bandung.

Sadoulet, E., de Janvry,.1995. A. Quantitative Development Policy Analysis. Baltimore: The Johns Hopkins University Press, 1995. 